\title{
NiO Nanoparticles: An Efficient Catalyst for the Multicomponent One-Pot Synthesis of Novel Spiro and Condensed Indole Derivatives
}

\author{
Harshita Sachdeva, Diksha Dwivedi, R. R. Bhattacharjee, Sarita Khaturia, and Rekha Saroj \\ Department of Chemistry, Faculty of Engineering and Technology, Mody Institute of Technology and Science, Sikar, Rajasthan, \\ Lakshmangarh 332311, India \\ Correspondence should be addressed to Harshita Sachdeva; drhmsachdevaster@gmail.com
}

Received 4 June 2012; Accepted 14 July 2012

Academic Editor: Esteban P. Urriolabeitia

Copyright (C) 2013 Harshita Sachdeva et al. This is an open access article distributed under the Creative Commons Attribution License, which permits unrestricted use, distribution, and reproduction in any medium, provided the original work is properly cited.

An efficient catalytic protocol for the synthesis of novel spiro[indoline-3,4 ${ }^{\prime}$-pyrano[2,3-c]thiazole]carbonitriles and condensed thiazolo $\left[5^{\prime \prime}, 4^{\prime \prime}: 5^{\prime}, 6^{\prime}\right]$ pyrano $\left[4^{\prime}, 3^{\prime}: 3,4\right]$ furo [2,3-b]indole derivatives is developed in a one-pot three-component approach involving substituted $1 \mathrm{H}$-indole-2,3-diones, activated methylene reagent, and 2-thioxo-4-thiazolidinone under conventional heating and microwave irradiation. This paper describes the use of $\mathrm{NiO}$ nanoparticles as catalyst for the synthesis of novel spiro and condensed indole derivatives by Knoevenagel condensation followed by Michael addition. The advantageous features of this methodology are operational simplicity, high yield processing, and easy handling. The particle size of $\mathrm{NiO}$ nanoparticle was determined by XRD. After reaction course, $\mathrm{NiO}$ nanoparticles can be recycled and reused without any apparent loss of activity.

\section{Introduction}

Catalysis lies at the heart of countless chemical protocols. The presence of a catalyst is mainly required by both modern organic synthesis and fine chemical industries. Nowadays, it plays a key role in the production of chemicals and materials as catalytic reactions occur under milder conditions compared to noncatalytic reactions [1-3]. Intensive studies have been recently focused on the development of catalytic systems owing to their importance in synthetic organic chemistry. One of the most attractive synthetic strategies favoured by organic chemists is the use of heterogeneous catalyst in increasing the efficiency of a wide range organic synthesis [4].

In recent times, transition metal nanoparticles are attracting a great deal of attention in almost any scientific and technological field, including catalysis $[5,6]$. Several reports [7-9] showed an amazing level of their performance as catalysts in terms of selectivity, reactivity, and improved yields of products. In addition, the high surface-to-volume ratio of nanoparticles provides a larger number of active sites per unit area compared to their heterogeneous counterparts. Thus, there has been a considerable increase in the interest in nanoparticles catalysis because of their high efficiency under environmentally benign reaction conditions [10-12]. Metal oxides represent a broad class of materials that have been researched extensively due to their interesting magnetic, electronic, and catalytic properties [13-16].

One possibility to extend the application of metal oxides as catalysts is to tailor their sizes in nanodimensions and hence their surface chemistry and catalytic properties. Recently, $\mathrm{NiO}$ nanoparticles have been employed as heterogeneous catalysts for various organic transformations [17]. An increasing number of examples are available in the literature where Nickel-based nanoparticles have been used as catalysts during organic transformations $[18,19]$. Since these nanoparticles are often recovered easily by simple workup, which prevent contamination of products, they may be considered as promising, safe, and reusable catalysts compared to traditional catalysts.

Indole and its derivatives are known as an important class of heterocyclic compounds in the pharmaceutical industry as well as in synthetic chemistry [20-23]. On the other hand, the spirooxindole unit is privileged heterocyclic motif that forms 


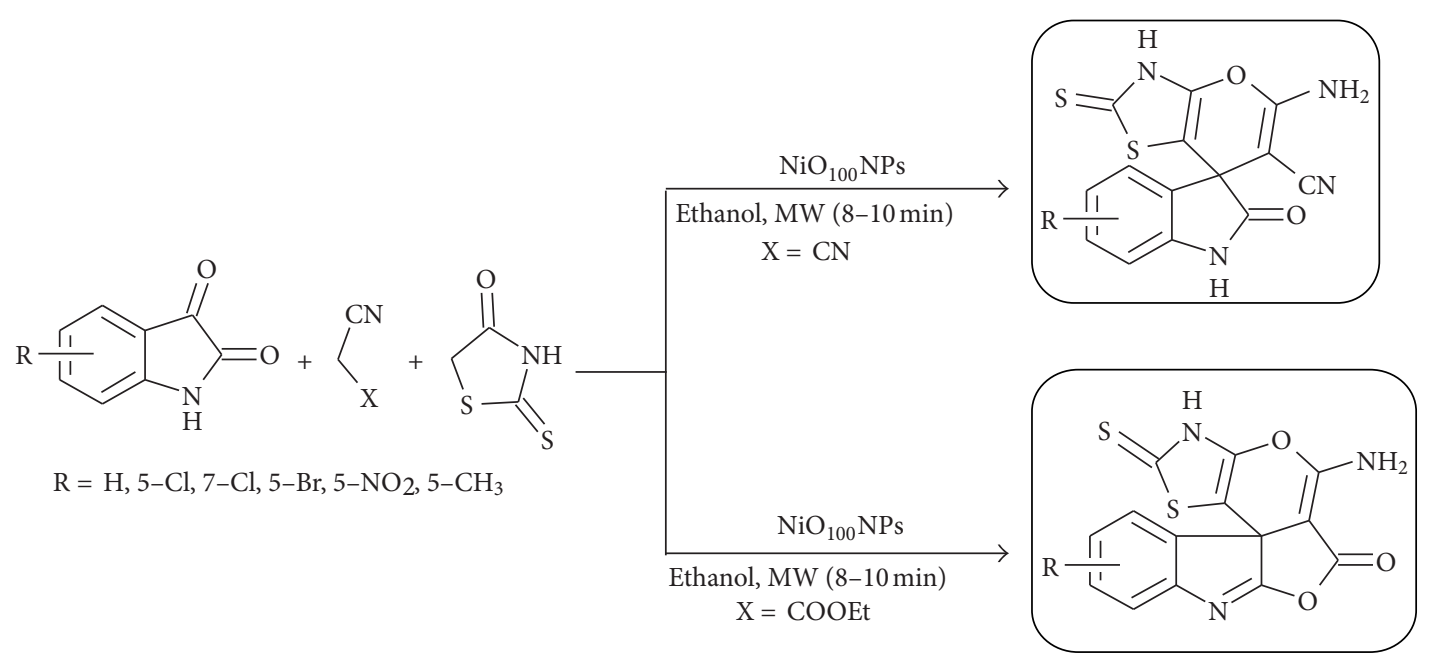

Scheme 1: Synthesis of spiro and condensed indole derivatives.

the core of a large family of alkaloid and natural products with strong bioactivity profiles and significant structural properties [24-31].

Among nitrogen-containing heterocyclic compounds, thiazoles are of immense interest to medicinal and industrial chemists due to their diverse biological activities such as antiglutamate, antiparkinson [32], antimicrobial [33], anthelmintic, anti-inflammatory [34], antihyperlipidemic, antihypertension and antioxidant properties as well as inhibition of enzymes such as acetylcholine esterase [35], aldose reductase [36], lipoxygenase [37], ATPase [38], and HCV helicase [39]. In general, heterocyclic systems encompassing pyran unit have found application as pharmaceuticals, agrochemicals, and veterinary products [40]. Further, pyrano thiazoles [4146] also possess wide range of bioactivity. It has been observed that the incorporation of more than one bioactive heterocyclic moiety into a single framework may result into the production of novel heterocycles with enhanced bioactivity. There are only few reports [47-49] available in the literature on the synthesis of pyranothiazoles but literature survey reveals no report on the synthesis of title novel nucleus so far.

Keeping in view of diverse biological activities associated with spiroindoles and pyrano thiazoles, it was thought to construct a novel system which may combine these bioactive rings together in a single molecular framework to see the additive effects towards their biological activities. Earlier [50, $51]$, we studied the reaction of $1 \mathrm{H}$-indol-2,3-diones and malononitrile with 1-phenyl-2-thiohydantoin and 2-pyrrolidone under conventional heating and microwave irradiation but the reaction of $1 \mathrm{H}$-indol-2,3-diones and malononitrile/ethyl cyanoacetate with 2-thioxo-4-thiazolidinone has not been studied so far. Hence, as a part of our ongoing program to develop efficient and robust methods for the preparation of biologically relevant compounds [52-57], we have developed a facile and efficient catalytic approach for the multicomponent one-pot synthesis of novel spiro[indolinepyranothiazole]carbonitriles (Scheme 1). The overall process involves the Knoevenagel condensation of 2-thioxo4-thiazolidinone with $1 \mathrm{H}$-indole-2,3-dione followed by "in situ” Michael addition of malononitrile in single operation.

In yet another attempt, we explored the reaction of $1 \mathrm{H}$ indole-2,3-dione and 2-thioxo-4-thiazolidinone with ethylcyanoacetate in absolute ethanol in the presence of $\mathrm{NiO}$ nanoparticles under microwave irradiation. The reaction surprisingly lead to the exclusive synthesis of 11-amino-2thioxo-10-oxo-thiazolo $\left[5^{\prime \prime}, 4^{\prime \prime}: 5^{\prime}, 6^{\prime}\right]$ pyrano $\left[4^{\prime}, 3^{\prime}: 3,4\right]$ furo[2, 3 -b]indole instead of the expected spiro compound in contrast to the earlier reports $[58,59]$ of the formation of spiroindoles in the reaction of 3-carboethoxycyanomethylene-2H-indol-2-ones with cyclic ketones under classical conditions but similar [60] to the results reported by us in the reaction of 3-carboethoxycyanomethylene$2 \mathrm{H}$-indol-2-ones with 1-phenyl-2-thiohydantoin leading to the synthesis of condensed indole derivatives. The formation of condensed product was assumed to involve the cycloaddition of less acidic indole- $\mathrm{OH}$ on the ester group of the intermediate spiro compound to form final isolated product (Scheme 2).

To the best of our knowledge, there is no report available in the literature describing the use of $\mathrm{NiO}$ nanoparticles as catalysts for the synthesis of spiro and condensed indole derivatives (Table 1). Here, we have used a combination of microwave conditions and $\mathrm{NiO}$ nanocatalyst to standardize the right conditions for the above reaction. The effectiveness of the process was studied by comparing the results obtained with and without catalyst under normal conditions (Table 2). Nanoparticle is considered to be more reacting because it offers higher surface area and low coordinating sites. The surface area of the catalyst increases tremendously when size decreases to nanolevels which are responsible for the higher catalytic activity and hence enhanced yields (Table 3 ). 
TABLE 1: Synthesis of Spiro and condensed indole derivatives under microwave irradiation using $\mathrm{Ni}_{100}$ nanoparticles.

\begin{tabular}{|c|c|c|c|c|c|c|}
\hline Entry & $\mathrm{R}$ & $\mathrm{X}$ & Time (min.) & Product & $\begin{array}{c}\text { Yield (\%) } \\
\mathrm{NiO}_{100} / \text { Piperidine }\end{array}$ & $\mathrm{MP}\left({ }^{\circ} \mathrm{C}\right)$ \\
\hline $5 \mathrm{a}$ & $\mathrm{H}$ & $\mathrm{CN}$ & 8 & $\mathrm{H}$ & $90 / 75$ & 298 \\
\hline $5 b$ & $5-\mathrm{Cl}$ & $\mathrm{CN}$ & 8 & & $87 / 72$ & 310 \\
\hline $5 c$ & 7-Cl & $\mathrm{CN}$ & 9 & & $87 / 74$ & 275 \\
\hline $5 d$ & $5-\mathrm{Br}$ & $\mathrm{CN}$ & 8 & $\mathrm{H}$ & $88 / 72$ & 270 \\
\hline $5 e$ & $5-\mathrm{NO}_{2}$ & $\mathrm{CN}$ & 10 & $\mathrm{H}$ & $90 / 72$ & 340 \\
\hline $5 \mathrm{f}$ & $5-\mathrm{CH}_{3}$ & $\mathrm{CN}$ & 8 & $\mathrm{H}$ & $88 / 70$ & 315 \\
\hline $5 g$ & $\mathrm{H}$ & COOEt & 8 & & $89 / 74$ & 332 \\
\hline $5 \mathrm{~h}$ & $5-\mathrm{Cl}$ & COOEt & 9 & & $87 / 73$ & 288 \\
\hline
\end{tabular}


TABLE 1: Continued.

\begin{tabular}{|c|c|c|c|c|c|c|}
\hline Entry & $\mathrm{R}$ & $\mathrm{X}$ & Time (min.) & Product & $\begin{array}{c}\text { Yield (\%) } \\
\mathrm{NiO}_{100} / \text { Piperidine }\end{array}$ & $\operatorname{MP}\left({ }^{\circ} \mathrm{C}\right)$ \\
\hline $5 i$ & 7-Cl & COOEt & 10 & & $88 / 73$ & 226 \\
\hline $5 \mathrm{j}$ & $5-\mathrm{Br}$ & COOEt & 9 & & $88 / 72$ & 347 \\
\hline $5 \mathrm{k}$ & $5-\mathrm{NO}_{2}$ & COOEt & 9 & & $84 / 74$ & 265 \\
\hline 51 & $5-\mathrm{CH}_{3}$ & COOEt & 10 & & $87 / 71$ & 356 \\
\hline
\end{tabular}

$\mathrm{NiO}_{100}$ is the nanoparticle calcined at $100^{\circ} \mathrm{C}$.

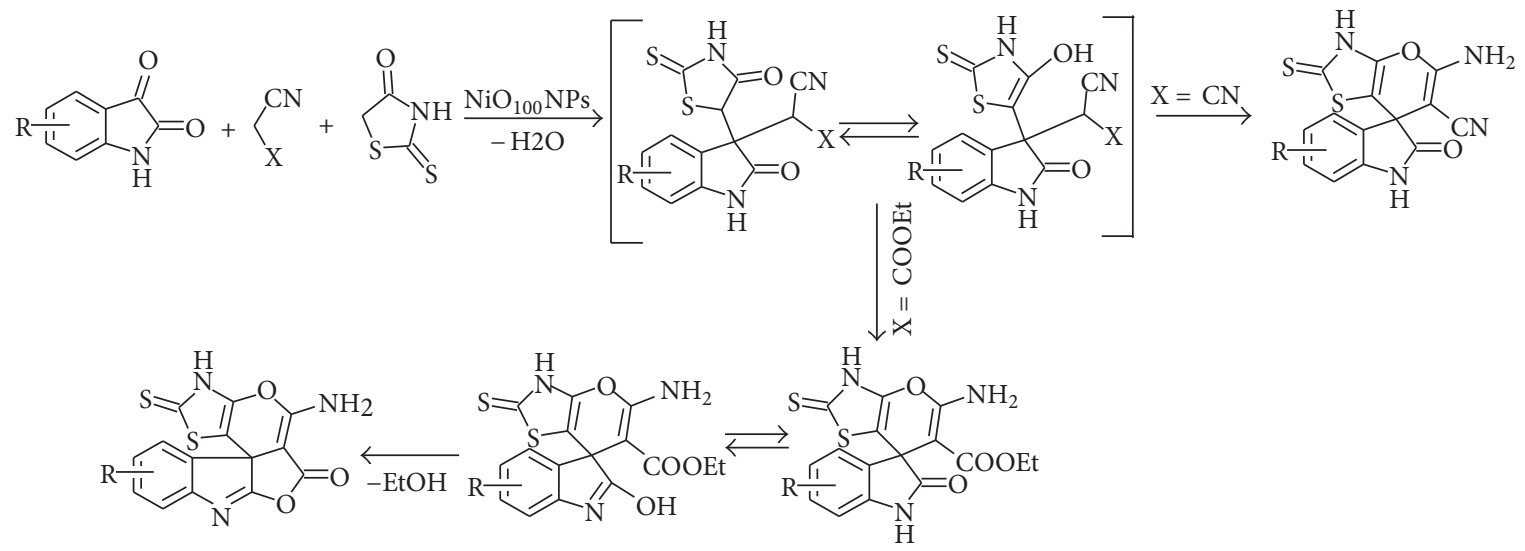

Scheme 2: Plausible Mechanism for the reaction of $1 \mathrm{H}$-indole-2,3-dione and malononitrile with 2-thioxo-4-thiazolidinone.

\section{Results and Discussion}

As a part of our ongoing interest aimed at developing new synthetic strategies for heterocyclic framework, the reaction of 1H-indole-2,3-dione, malononitrile/ethylcyanoacetate, and 2-thioxo-4-thiazolidinone was examined in the presence of catalytic amount $(20 \mathrm{mg})$ of $\mathrm{NiO}$ nanoparticle under microwave irradiation to give novel spiro[indoline- $3,4^{\prime}$-pyrano[2,3-c]thiazole] carbonitrile and condensed thiazolo[ $5^{\prime \prime}$, $\left.4^{\prime \prime}: 5^{\prime}, 6^{\prime}\right]$ pyrano $\left[4^{\prime}, 3^{\prime}: 3,4\right]$ furo $[2,3-\mathrm{b}]$ indole derivatives.

After some preliminary experiments, we found that a mixture of $1 \mathrm{H}$-indole-2,3-dione malononitrile/ethylcyanoacetate and 2-thioxo-4-thiazolidinone in the presence of $\mathrm{NiO}$ nanoparticle afforded products in excellent yield (84-90\%) 
TABLE 2: Comparison of catalytic activity of $\mathrm{NiO}_{100}$ nanoparticle with piperidine in the synthesis of compound $5 \mathrm{a}$ and $5 \mathrm{~g}$ by conventional and microwave irradiation methods.

\begin{tabular}{|c|c|c|c|c|}
\hline Entry & Conditions & Type of catalysts & Reaction time (hr/min.) & Yield (\%) \\
\hline \multirow{6}{*}{$5 a$} & MW & No catalyst & $30 \mathrm{~min}$ & 40 \\
\hline & MW & Piperidine & $16 \mathrm{~min}$. & 75 \\
\hline & MW & $\mathrm{NiO}_{100}$ & $8 \mathrm{~min}$. & 90 \\
\hline & $\Delta$ & No catalyst & $30 \mathrm{hrs}$ & 35 \\
\hline & $\Delta$ & Piperidine & $13 \mathrm{hrs}$ & 52 \\
\hline & $\Delta$ & $\mathrm{NiO}_{100}$ & 8 hrs & 67 \\
\hline \multirow{6}{*}{$5 g$} & MW & No catalyst & $30 \mathrm{~min}$. & 32 \\
\hline & MW & Piperidine & $16 \mathrm{~min}$. & 74 \\
\hline & MW & $\mathrm{NiO}_{100}$ & $8 \mathrm{~min}$ & 89 \\
\hline & $\Delta$ & No catalyst & $30 \mathrm{hrs}$ & 25 \\
\hline & $\Delta$ & Piperidine & $14 \mathrm{hrs}$ & 50 \\
\hline & $\Delta$ & $\mathrm{NiO}_{100}$ & $9 \mathrm{hrs}$ & 65 \\
\hline
\end{tabular}

TABLE 3: Comparison of catalytic activity of $\mathrm{NiO}$ nanoparticle calcined at $100^{\circ} \mathrm{C}\left(\mathrm{NiO}_{100}\right), 200^{\circ} \mathrm{C}\left(\mathrm{NiO}_{200}\right), 400^{\circ} \mathrm{C}\left(\mathrm{NiO}_{400}\right)$ in the synthesis of the compound 5 a under conventional heating and microwave irradiation methods.

\begin{tabular}{|c|c|c|c|c|c|c|}
\hline \multirow{2}{*}{ Entry } & \multirow{2}{*}{ Type of catalyst } & \multicolumn{2}{|c|}{ Time (hr/min.) } & \multicolumn{2}{|c|}{ Yield (\%) } & \multirow{2}{*}{ Particle size $(\mathrm{nm})$} \\
\hline & & $\Delta$ & MW & $\Delta$ & MW & \\
\hline 1 & $\mathrm{NiO}_{100}$ & $8 \mathrm{hrs}$ & $8 \mathrm{~min}$. & 67 & 90 & 9.7 \\
\hline 2 & $\mathrm{NiO}_{200}$ & $12 \mathrm{hrs}$ & $13 \mathrm{~min}$. & 60 & 82 & 18 \\
\hline 3 & $\mathrm{NiO}_{400}$ & $16 \mathrm{hrs}$ & $17 \mathrm{~min}$. & 53 & 78 & - \\
\hline
\end{tabular}

TABLE 4: Optimization of reaction conditions ${ }^{\mathrm{a}}$.

\begin{tabular}{lcc}
\hline Entry & Catalysts $(\mathrm{mg})$ & Yield (\%) \\
\hline 1 & 10 & 83 \\
2 & 20 & 90 \\
3 & 30 & 90 \\
\hline
\end{tabular}

${ }^{\mathrm{a}}$ The reaction was carried out with $1 \mathrm{H}$-indole-2,3-dione, malononitrile and 2-thioxo-4-thiazolidinone under microwave irradiation.

(Table 1) and with piperidine catalyst, the product formed with yields ranging between 72 and $75 \%$.

In order to confirm the effective involvement of $\mathrm{NiO}$ nanoparticle during this transformation, we carried out the model reaction without any catalyst. In the absence of $\mathrm{NiO}$ nanoparticle, the reaction was incomplete even after 30 minutes of microwave irradiation though small amount of compound (40\%) (Table 2) was observed. To verify the specific effect of microwaves, we also performed the experiment under conventional heating without using any catalyst. The synthesis of compound was carried out by refluxing for $30 \mathrm{hrs}$ resulting in $25-35 \%$ yields while under microwave irradiation for $30 \mathrm{~min}$. compound was obtained in $32-40 \%$ yields. It showed that microwave irradiation was found to have a beneficial effect on the synthesis of spiro/condensed indole derivatives (Table 2).

Encouraged by these results, we have extended this reaction to variously substituted $1 \mathrm{H}$-indole-2,3-diones under similar conditions to furnish the respective spiro/condensed indole derivatives in excellent yields (84-90\%) without the formation of any side products (Table 1). Compounds were also synthesized under conventional heating using piperidine/ $\mathrm{NiO}$ nanoparticle catalyst but yield of the product was found to be low as compared to that obtained with microwave heating and it was observed that better yield was obtained in the presence of $\mathrm{NiO}$ nanoparticles even under conventional heating (Table 2).

To find the most effective catalyst for the synthesis of novel spiro and condensed indole derivatives under microwave irradiation, $\mathrm{NiO}$ nanoparticles obtained were calcined at different temperatures and their catalytic effect was studied. It was observed that particle size increased with increase in calcinations temperature from $100^{\circ} \mathrm{C}$ to $400^{\circ} \mathrm{C}$ and hence catalytic activity reduced (Table 3 ). When the reaction was carried out in the presence of $100^{\circ} \mathrm{C}$ calcined $\mathrm{NiO}$ nanoparticles, yield obtained was much higher (90\%) as compared to that carried out in the presence of $200^{\circ} \mathrm{C}(82 \%)$ and $400^{\circ} \mathrm{C}(78 \%)$ calcined nanoparticles under microwave irradiation (Table 3). This may be due to decrease in surface area of $\mathrm{NiO}$ nanoparticle.

Further, we have also emphasized the amount of $100^{\circ} \mathrm{C}$ calcined $\mathrm{NiO}$ nanoparticle to be used in this condensation reaction (Table 4). Adding $30 \mathrm{mg}$ of $100^{\circ} \mathrm{C}$ calcined $\mathrm{NiO}$ nanoparticle to the system under similar conditions resulted in obvious acceleration but the yield was not improved. While increasing the amount of $\mathrm{NiO}$ nanoparticle from $10 \mathrm{mg}$ to $20 \mathrm{mg}$ the reaction resulted in the formation of final compound in $83 \%$ and $90 \%$, respectively. Thus best results were obtained when $20 \mathrm{mg}$ of $\mathrm{NiO}$ nanoparticle was used. A higher amount of catalyst did not improve the results to an appreciable extent. 


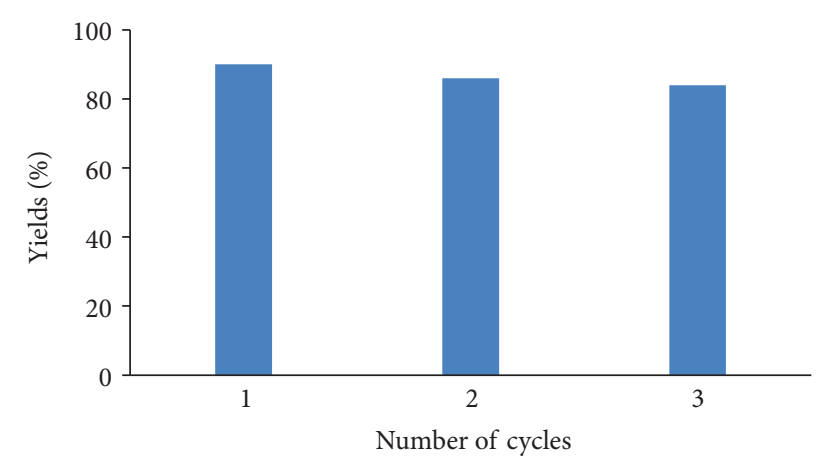

FIGURE 1: Recyclability of NiO nanoparticles.

Reusability (and hence recyclability) is one of the important properties of this catalyst. In this study, the catalyst was recovered by filtration from the reaction mixture and reused during three consecutive runs without any apparent loss of activity for the same reaction Figure 1.

The syntheses of the $\mathrm{NiO}$ nanoparticles were performed according to a literature method developed by Sun and Sirringhaus [61] with slight modification. The structure of $\mathrm{NiO}$ nanoparticles has been studied at room temperature by using $\mathrm{X}$-ray diffraction pattern. Figure 2 shows XRD pattern of $\mathrm{NiO}$ nanoparticles calcined at $100^{\circ} \mathrm{C}$. As reported in the literature [62], variation of ageing temperature has a profound effect on the unit cell lattice of metal oxide nanoparticles. Table 3 shows how variation of this parameter affects particle size. The particle sizes were calculated from X-ray diffraction images of $\mathrm{NiO}$ powders using Scherrer formula [63]:

$$
\mathrm{D}=\frac{K \lambda}{\beta \cos \theta},
$$

where $K$ is constant, $\lambda$ is wavelength of X-rays employed radiation, $\beta$ is full width at half $\max (\mathrm{FWHM})$, and $\theta$ is the diffraction angle.

A conceivable mechanism for the formation of the product would be as follows. The $\mathrm{NiO}$ nanoparticle facilitates the Knoevenagel-type coupling through Lewis acid sites $\left(\mathrm{Ni}^{+2}\right)$ [4] coordinated to the oxygen of carbonyl groups. On the other hand, $\mathrm{NiO}$ nanoparticles can activate methylene compounds so that deprotonation of the $\mathrm{C}-\mathrm{H}$ bond occurs in the presence of Lewis basic sites $\left(\mathrm{O}^{-2}\right)$. As a result, the formation of spiro indole derivatives proceeds by activation of reactants through both Lewis acids and basic sites of $\mathrm{NiO}$ nanoparticles. The formation of condensed product was assumed to involve the cycloaddition of less acidic indole$\mathrm{OH}$ on the ester group of the intermediate spiro compound to form final isolated product (Scheme 2).

\section{Conclusion}

In conclusion, we have demonstrated a novel and highly efficient catalytic approach for the synthesis of structurally complex and diverse spiro and condensed indole derivatives catalyzed effectively by $\mathrm{NiO}$ nanoparticles involving Michael and Knoevenagel condensation. $\mathrm{NiO}$ nanoparticles are well characterized by XRD technique. This method offers several advantages including avoidance of harmful organic solvents, high yield, short reaction time, a simple work-up procedure, ease of separation, and recyclability of the catalyst, as well as ability to tolerate a wide variety of substitutions in the components.

\section{Experimental Section}

4.1. General. Reagents and solvents were obtained from commercial sources and used without further purification. Melting points were determined on a Toshniwal apparatus. The spectral analyses of synthesized compounds have been carried out at SAIF, Punjab University, Chandigarh. Purity of all compounds was checked by TLC using " $G$ " coated glass plates and $n$-hexane: ethyl acetate $(7: 3)$ as eluent. IR spectra were recorded in $\mathrm{KBr}$ on a Perkin Elmer Infrared RXI FTIR spectrophotometer and ${ }^{1}$ HNMR spectra were recorded on Bruker Avance II 400 NMR Spectrometer using DMSO$\mathrm{d}_{6}$ and $\mathrm{CDCl}_{3}$ as solvent and tetramethylsilane (TMS) as internal reference standard. The obtained products were identified from their spectral $\left({ }^{1} \mathrm{HNMR},{ }^{13} \mathrm{C} \mathrm{NMR}\right.$, and IR) data. The microwave-assisted reactions were carried out in a Catalysts Systems Scientific Multimode MW oven attached with a magnetic stirrer and reflux condenser, operating at $700 \mathrm{~W}$ generating $2450 \mathrm{MHz}$ frequency.

4.2. General Procedure for the Synthesis of NiO Nanoparticles. $\mathrm{NiO}$ precursors were synthesized by the sol-gel reaction and then calcined to obtain $\mathrm{NiO}$ nanoparticles. Firstly, nickel acetate $\left(\mathrm{Ni}(\mathrm{Ac})_{2} 0.646 \mathrm{~g}, 2.6 \mathrm{mmol}\right)$ and $250 \mu \mathrm{L}$ of water were added in to a flask containing $42 \mathrm{~mL}$ of methanol. The solution was heated to $60^{\circ} \mathrm{C}$ with magnetic stirring. Potassium hydroxide ( $\mathrm{KOH}, 0.485 \mathrm{~g}$ ) was dissolved into $23 \mathrm{~mL}$ of methanol as the stock solution that was dropped into the flask within $10-15 \mathrm{~min}$. At a constant temperature of $60^{\circ} \mathrm{C}$, it took $2 \mathrm{hrs}$ and $15 \mathrm{~min}$. A small amount of water was found helpful to increase the $\mathrm{NiO}$ nanocrystal growth rate. To grow the nanorods, the solution was condensed to about $10 \mathrm{~mL}$. This was found helpful before further heating to decrease the growth time of the nanorods. Then it was reheated for another $5 \mathrm{hrs}$ before stopping the heating and stirring. The upper fraction of the solution was removed after $30 \mathrm{~min}$. Methanol $(50 \mathrm{~mL})$ was added to the solution and stirred for $5 \mathrm{~min}$. The upper fraction of the solution was discarded again after $30 \mathrm{~min}$. This process was repeated twice. After being dried under vacuum, the precursors were calcined in oven at various temperatures $\left(100^{\circ} \mathrm{C}, 200^{\circ} \mathrm{C}\right.$, and $400^{\circ} \mathrm{C}$ ) for 2 hrs and then $\mathrm{NiO}$ nanoparticles were obtained.

4.3. Regeneration of Catalyst. To examine the reusability, the catalyst recovered by filtration from the reaction mixture after dilution with ethyl acetate was reused as such for subsequent experiments (up to three cycles) under similar reaction conditions. The observed fact that yields of the product remained comparable in these experiments (Figure 1) established the recyclability and reusability of the catalyst without any significant loss of activity. 


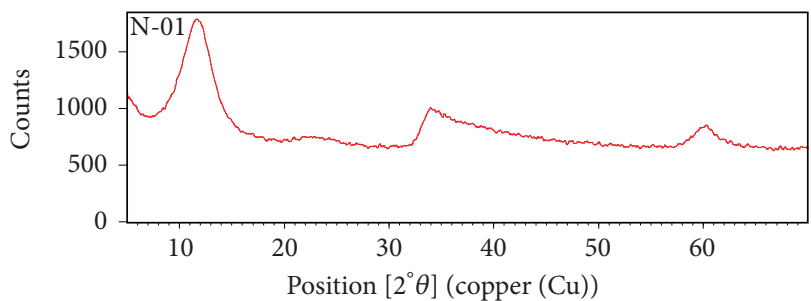

\begin{tabular}{lcccc}
\hline $\begin{array}{l}\text { Pos. } \\
\left({ }^{\circ} 2 \mathrm{Th} .\right)\end{array}$ & $\begin{array}{c}\text { FWHM } \\
\left({ }^{\circ} 2 \mathrm{Th} .\right)\end{array}$ & $\begin{array}{c}d \text {-spacing } \\
(\AA)\end{array}$ & $\begin{array}{c}\text { Rel. Int. } \\
(\%)\end{array}$ & $\begin{array}{c}\text { Area } \\
\left(\text { cts* } *^{\circ} 2 \mathrm{Th} .\right)\end{array}$ \\
\hline 11.6450 & 1.4691 & 7.59942 & 100.00 & 829.18 \\
34.0614 & 1.1880 & 2.63223 & 57.83 & 258.50 \\
60.2907 & 0.3628 & 1.53513 & 50.65 & 103.70 \\
\hline
\end{tabular}

FIGURE 2: XRD pattern of $\mathrm{NiO}_{100}$ nanoparticle.

4.4. General Procedure for the Synthesis of Compounds 5 and 6 under Microwave Irradiation. An equimolar mixture $(1 \mathrm{mmol})$ of $1 \mathrm{H}$-indole-2,3-dione $(0.147 \mathrm{~g})$, malononitrile $(0.066 \mathrm{~g}) /$ ethylcynoacetate $(0.113 \mathrm{~g})$ and 2-thioxo-4thiazolidinone $(0.133 \mathrm{~g})$, in absolute ethanol $(15 \mathrm{~mL})$ in the presence of piperidine $(2-3$ drops $) / \mathrm{NiO}_{100}(20 \mathrm{mg})$ was charged into a glass microwave vessel and refluxed inside a microwave oven at 420 Watts for $16-18 \mathrm{~min} . / 8-10 \mathrm{~min}$., respectively. Progress of the reaction was monitored by TLC. After completion of the reaction, reaction mixture was cooled to room temperature and the excess solvent was evaporated on rota-evaporator to give a solid, which was dried and recrystallised from ethyl acetate.

\subsection{Characterization Data}

4.5.1. $6^{\prime}$-Amino-2 ${ }^{\prime}$-thioxo-2-oxo- $1^{\prime} H$-spiro[indoline- $3,4^{\prime}$-pyrano[2,3-c]thiazole]-5' -carbonitrile(5a). Brown solid, $\mathrm{mp}$ 296-298 ${ }^{\circ}$ C, Yield ( $\mathrm{NiO}_{100} /$ Piperidine) 90/75\%, 0.269/0.246 g; IR $(\mathrm{KBr}) v 3400,3265,3059,3008,2220,1710,1300 \mathrm{~cm}^{-1}$; ${ }^{1} \mathrm{HNMR}(400 \mathrm{MHz}, \mathrm{DMSO}) \delta 11.21$ (s. $1 \mathrm{H}, \mathrm{NH}$ indole), $7.94\left(\mathrm{~s}, 2 \mathrm{H}, \mathrm{NH}_{2}\right), 6.93-8.75(\mathrm{~m}, 4 \mathrm{H}, \mathrm{Ar}-\mathrm{H}), 2.88$ (s, 1H, $\mathrm{NH})$ ppm; ${ }^{13} \mathrm{CNMR}(400 \mathrm{MHz}, \mathrm{DMSO}): 193.96,185.54$, $169.63,161.47,144.95,142.98,137.79,129.74,127.17$, $121.28,119.08,77.27,61.05,59.42,45.26$ ppm. Anal. Calcd for $\mathrm{C}_{14} \mathrm{H}_{8} \mathrm{~N}_{4} \mathrm{O}_{2} \mathrm{~S}_{2}$ : C, 51.21; $\mathrm{H}, 2.46 ; \mathrm{N}, 17.06$. Found: $\mathrm{C}$, 51.38; H, 2.48; N, 17.03; MS: $[\mathrm{M}]^{+}$at $m / z 328.01$.

4.5.2. $6^{\prime}$-Amino- $2^{\prime}$-thioxo-5-chloro-2-oxo- $1^{\prime} H$-spiro [indoline-3,4'-pyrano[2,3-c] thiazole]-5' -carbonitrile $(\mathbf{5 b})$. Brown solid, mp $310-312^{\circ} \mathrm{C}$, Yield $\left(\mathrm{NiO}_{100} /\right.$ Piperidine) $87 / 72 \%$, 0.315/0.262 g; IR (KBr) v 3450, 3225, 3052, 3028, 2120, 1685, $1320 \mathrm{~cm}^{-1}$; ${ }^{1} \mathrm{HNMR}$ (400 MHz, DMSO) $\delta 11.12$ (s. $1 \mathrm{H}, \mathrm{NH}$ indole), $8.78\left(\mathrm{~s}, 2 \mathrm{H}, \mathrm{NH}_{2}\right), 6.99-8.02(\mathrm{~m}, 3 \mathrm{H}, \mathrm{Ar}-\mathrm{H}), 2.82$ (s, 1H, NH) ppm; ${ }^{13} \mathrm{CNMR}(400 \mathrm{MHz}, \mathrm{DMSO}): 189.88$, $153.55,150.67,150.67,147.04,144.56,129.69,121.54$, 120.56, 105.99, 77.06, 61.02, 56.26, 44.92 ppm. Anal. Calcd for $\mathrm{C}_{14} \mathrm{H}_{7} \mathrm{ClN}_{4} \mathrm{O}_{2} \mathrm{~S}_{2}$ : C, 46.35; $\mathrm{H}, 1.94 ; \mathrm{N}, 15.44$. Found: $\mathrm{C}$, 46.35; H, 1.92; N, 15.47; MS: [M] $]^{+}$at $m / z 361.97$.
4.5.3. $\quad 6^{\prime}$-Amino- $2^{\prime}$-thioxo-7-chloro-2-oxo- $1^{\prime} H$-spiro[indoline-3, $4^{\prime}$-pyrano[2,3-c] thiazole]-5' -carbonitrile $(5 \mathbf{c})$. Brown solid, mp $275-277^{\circ} \mathrm{C}$, Yield $\left(\mathrm{NiO}_{100} /\right.$ Piperidine) $87 / 74 \%$, 0.315/0.269 g; IR (KBr) v 3310, 3115, 3039, 3020, 2215, 1720, $1340 \mathrm{~cm}^{-1}$. ${ }^{1} \mathrm{HNMR}$ (400 MHz, DMSO) $\delta 11.58$ (s. $1 \mathrm{H}, \mathrm{NH}$ indole), 7.19 (s, 2H, $\mathrm{NH}_{2}$ ), 6.97-8.63 (m, 3H, Ar-H), 2.98 (s, 1H, NH) ppm; ${ }^{13} \mathrm{CNMR}(400 \mathrm{MHz}, \mathrm{DMSO}) \delta 193.12$, $188.22,169.41,160.26,142.46,141.76,135.34,126.13$, $121.04,114.71,77.64 .08,56.83,44.33$ ppm. Anal. Calcd for $\mathrm{C}_{14} \mathrm{H}_{7} \mathrm{ClN}_{4} \mathrm{O}_{2} \mathrm{~S}_{2}: \mathrm{C}, 46.35 ; \mathrm{H}, 1.94 ; \mathrm{N}, 15.44$. Found: C, 46.14; H, 1.96; N, 15.41; MS: [M] $]^{+}$at $m / z 361.97$.

4.5.4. $\quad 6^{\prime}$-Amino- $2^{\prime}$-thioxo-5-bromo-2-oxo- $1^{\prime} H$-spiro[indoline-3,4' -pyrano[2,3-c] thiazole]-5' -carbonitrile(5d). Brown solid, mp $270-272^{\circ} \mathrm{C}$, Yield $\left(\mathrm{NiO}_{100} /\right.$ Piperidine) $88 / 72 \%$, 0.360/0.294 g; IR (KBr) v 3410, 3132, 3019, 3012, 2235, 1690, $1335 \mathrm{~cm}^{-1}$. ${ }^{1} \mathrm{HNMR}$ (400 MHz, DMSO) $\delta 11.04$ (s. $1 \mathrm{H}, \mathrm{NH}$ indole), $8.02\left(\mathrm{~s}, 2 \mathrm{H}, \mathrm{NH}_{2}\right), 6.87-8.53(\mathrm{~m}, 3 \mathrm{H}, \mathrm{Ar}-\mathrm{H}), 2.93$ (s, 1H, NH) ppm; ${ }^{13} \mathrm{CNMR}$ (400 MHz, DMSO) 192.23, $183.71,166.42,143.32,140.11,131.44,124.92,122.11$, 118.12, 111.76, 78.04, 64.25, 59.06, 44.17 ppm. Anal. Calcd for $\mathrm{C}_{14} \mathrm{H}_{7} \mathrm{BrN}_{4} \mathrm{O}_{2} \mathrm{~S}_{2}$ : C, 41.48; $\mathrm{H}, 1.73 ; \mathrm{N}, 13.76$. Found: C, 41.48; H, 1.70; N, 13.74; MS: [M] $]^{+}$at $m / z 405.92$.

4.5.5. $6^{\prime}$-Amino-2' ${ }^{\prime}$-thioxo-5-nitro-2-oxo- $1^{\prime}$ H-spiro[indoline$3,4^{\prime}$-pyrano[2,3-c]thiazole]-5'-carbonitrile $(\mathbf{5 e})$. Brown solid, mp 340-342 C, Yield ( $\mathrm{NiO}_{100} /$ Piperidine) 90/72\%, 0.337/ $0.269 \mathrm{~g}$; IR $(\mathrm{KBr}) v 3410,3132,3021,3112,2225,1693$, $1320 \mathrm{~cm}^{-1}$. ${ }^{1} \mathrm{HNMR}$ (400 MHz, DMSO) $\delta 11.01$ (s. $1 \mathrm{H}, \mathrm{NH}$ indole), 8.01 ( $\left.\mathrm{s}, 2 \mathrm{H}, \mathrm{NH}_{2}\right), 6.83-8.43(\mathrm{~m}, 3 \mathrm{H}, \mathrm{Ar}-\mathrm{H}), 2.83$ (s, $1 \mathrm{H}, \mathrm{NH}) \mathrm{ppm} .{ }^{13} \mathrm{CNMR}$ (400 MHz, DMSO) 191.25, 185.62, 164.30, 143.51, 141.73, 135.81, 126.17, 121.45, 117.33, 78.54, 61.07, 59.31, 42.27 ppm. Anal. Calcd for $\mathrm{C}_{14} \mathrm{H}_{7} \mathrm{~N}_{5} \mathrm{O}_{4} \mathrm{~S}_{2}$ : C, 45.04; H, 1.89; N, 18.76. Found: C, 45.22; H, 1.91; N, 18.73; MS: $[\mathrm{M}]^{+}$at $m / z 372.99$.

4.5.6. $\quad 6^{\prime}$-Amino-2 $2^{\prime}$-thioxo-5-methyl-2-oxo- $1^{\prime} H$-spiro[indoline-3, $4^{\prime}$-pyrano[2,3-c]thiazole]-5'-carbonitrile(5f). Brown 
solid, mp $315-317^{\circ} \mathrm{C}$, Yield $\left(\mathrm{NiO}_{100} /\right.$ Piperidine) $88 / 70 \%$, 0.301/0.241 g; IR (KBr) v 3350, 3125, 3042, 3088, 2120, 1689, $1330 \mathrm{~cm}^{-1}$. ${ }^{1} \mathrm{HNMR}$ (400 MHz, DMSO) $\delta 10.91$ (s. $1 \mathrm{H}, \mathrm{NH}$ indole), $8.65\left(\mathrm{~s}, 2 \mathrm{H}, \mathrm{NH}_{2}\right), 6.81-8.02(\mathrm{~m}, 3 \mathrm{H}, \mathrm{Ar}-\mathrm{H}), 3.37$ $\left(\mathrm{s}, 3 \mathrm{H}, \mathrm{CH}_{3}\right), 2.81$ (s, 1H, NH) ppm; ${ }^{13} \mathrm{CNMR}(400 \mathrm{MHz}$, DMSO) 191.54, 183.42, 169.55, 144.07, 141.52, 137.92, $126.76,120.04,117.15,77.78,62.22,59.64,45.33$ ppm. Anal. Calcd for $\mathrm{C}_{15} \mathrm{H}_{10} \mathrm{~N}_{4} \mathrm{O}_{2} \mathrm{~S}_{2}$ : C, 52.62; H, 2.94; N, 16.36. Found: C, 52.83; H, 2.92; N, 16.39; MS: [M] $]^{+}$at $m / z 342.02$.

4.5.7. 11-Amino-2-thioxo-10-oxo-thiazolo $\left[5^{\prime \prime}, 4^{\prime \prime}: 5^{\prime}, 6^{\prime}\right]$ pyrano $\left[4^{\prime}, 3^{\prime}: 3,4\right]$ furo $[2,3-b]$ indole $(5 g)$. Brown solid, $\mathrm{mp}$ 332-334 ${ }^{\circ} \mathrm{C}$, Yield $\left(\mathrm{NiO}_{100} /\right.$ Piperidine $)$ 89/74\%, $0.293 \mathrm{~g} / 0.241$; IR $(\mathrm{KBr}) v 3430,3225,3059,3018,1710,1320 \mathrm{~cm}^{-1} ;{ }^{1} \mathrm{HNMR}$ (400 MHz, DMSO) $\delta 11.11$ (s. $1 \mathrm{H}, \mathrm{NH}$ indole), 7.24 (s, 2H, $\left.\mathrm{NH}_{2}\right)$, 6.91-8.15 (m, 4H, Ar-H), 2.70 (s, 1H, NH) ppm; ${ }^{13}$ CNMR (400 MHz, DMSO) 192.49, 168.41, 142.73, 131.47, $127.33,123.64,120.87,111.34,77.88,35.95,30.03$ ppm. Anal. Calcd for $\mathrm{C}_{14} \mathrm{H}_{7} \mathrm{~N}_{3} \mathrm{O}_{3} \mathrm{~S}_{2}$ : C, 51.05; $\mathrm{H}, 2.14 ; \mathrm{N}, 12.76$. Found: C, $50.87 ; \mathrm{H}, 2.13 ; \mathrm{N}, 12.79$; MS: $[\mathrm{M}]^{+}$at $m / z 328.99$.

4.5.8. 11-Amino-2-thioxo-5-chloro-10-oxo-thiazolo $\left[5^{\prime \prime}, 4^{\prime \prime}\right.$ : $\left.5^{\prime}, 6^{\prime}\right]$ pyrano $\left[4^{\prime}, 3^{\prime}: 3,4\right]$ furo $[2,3-b]$ indole $(\mathbf{5 h})$. Brown solid, mp $288-291^{\circ} \mathrm{C}$, Yield $\left(\mathrm{NiO}_{100} /\right.$ Piperidine) $87 / 73 \%$, 0.319/0.267 g; IR (KBr) v 3330, 3231, 3039, 3018, 1710, $1340 \mathrm{~cm}^{-1}$; ${ }^{1} \mathrm{HNMR}$ (400 MHz, DMSO) $\delta 11.24$ (s. $1 \mathrm{H}, \mathrm{NH}$ indole), 7.34 (s, $2 \mathrm{H}, \mathrm{NH}_{2}$ ), 6.82-8.05 (m, 3H, Ar-H), 2.98 (s, 1H, NH). ${ }^{13} \mathrm{CNMR}(400 \mathrm{MHz}, \mathrm{DMSO}) 193.26,169.41$, $167.43,142.97,131.43,126.04,123.25,121,111.64,78.74$, 39.05 ppm. Anal. Calcd for $\mathrm{C}_{14} \mathrm{H}_{6} \mathrm{ClN}_{3} \mathrm{O}_{3} \mathrm{~S}_{2}$ : C, 46.22; $\mathrm{H}$, 1.66; N, 11.55. Found: C, 46.05; H, 1.64; N, 11.52; MS: [M] ${ }^{+}$ at $m / z 362.95$.

4.5.9. 11-Amino-2-thioxo-7-chloro-10-oxo-thiazolo $\left[5^{\prime \prime}, 4^{\prime \prime}\right.$ : $\left.5^{\prime}, 6^{\prime}\right]$ pyrano $\left[4^{\prime}, 3^{\prime}: 3,4\right]$ furo[2,3-b]indole(5i). Brown solid, $\mathrm{mp} \quad 226-228^{\circ} \mathrm{C}$, Yield $\left(\mathrm{NiO}_{100} /\right.$ Piperidine $) \quad 88 / 73 \%$, 0.325/0.267 g; IR (KBr) v 3430, 3231, 3039, 3018, 1690, $1330 \mathrm{~cm}^{-1}{ }^{1} \mathrm{HNMR}$ (400 MHz, DMSO) $\delta 11.50$ (s. $1 \mathrm{H}, \mathrm{NH}$ indole), 7.54 (s, 2H, $\mathrm{NH}_{2}$ ), 6.91-8.17 (m, 3H, Ar-H), 2.82 (s, 1H, NH) ppm; ${ }^{13} \mathrm{CNMR}(400 \mathrm{MHz}, \mathrm{DMSO}) 191.52$, $161.75,159.02,142.15,134.06,123.66,120.34,112.35,76.56$, $38.46 \mathrm{ppm}$. Anal. Calcd for $\mathrm{C}_{14} \mathrm{H}_{6} \mathrm{ClN}_{3} \mathrm{O}_{3} \mathrm{~S}_{2}$ : C, 46.22; $\mathrm{H}$, 1.66; N, 11.55. Found: C, 46.40; H, 1.64; N, 11.57; MS: [M] ${ }^{+}$ at $m / z 362.95$.

4.5.10. 11-Amino-2-thioxo-5-bromo-10-oxo-thiazolo $\left[5^{\prime \prime}, 4^{\prime \prime}\right.$ : $\left.5^{\prime}, 6^{\prime}\right]$ pyrano $\left[4^{\prime}, 3^{\prime}: 3,4\right]$ furo $[2,3-b]$ indole $(5 \mathbf{j})$. Brown solid, $\mathrm{mp} 347-348^{\circ} \mathrm{C}$, Yield (\%) $\left(\mathrm{NiO}_{100} /\right.$ Piperidine) $88 / 72 \%$, 0.360/0.295 g; IR (KBr) v 3423, 3231, 3029, 3078, 1692, $1340 \mathrm{~cm}^{-1} ;{ }^{1} \mathrm{HNMR}$ (400 MHz, DMSO) $\delta 11.51$ (s. $1 \mathrm{H}, \mathrm{NH}$ indole), 7.13 (s, $2 \mathrm{H}, \mathrm{NH}_{2}$ ), 6.98-8.63 (m, 3H, Ar-H), 2.81 (s, $1 \mathrm{H}, \mathrm{NH}) \mathrm{ppm} ;{ }^{13} \mathrm{CNMR}$ (400 MHz, DMSO) 193.02, 167.35, $161.64,154.83,143.57,137.01,126,121.08,117.24,76.52$. 38.50 ppm. Anal. Calcd for $\mathrm{C}_{14} \mathrm{H}_{6} \mathrm{BrN}_{3} \mathrm{O}_{3} \mathrm{~S}_{2}$ : C, 41.19; $\mathrm{H}$, 1.48; N, 10.29. Found: C, 41.40; H, 1.50; N, 10.26; MS: [M] ${ }^{+}$ at $m / z 406.90$.
4.5.11. 11-Amino-2-thioxo-5-nitro-10-oxo-thiazolo $\left[5^{\prime \prime}, 4^{\prime \prime}\right.$ : $\left.5^{\prime}, 6^{\prime}\right]$ pyrano $\left[4^{\prime}, 3^{\prime}: 3,4\right]$ furo $[2,3-b]$ indole(5k). Brown solid, $\mathrm{mp} \quad 265-267^{\circ} \mathrm{C}$, Yield $\left(\mathrm{NiO}_{100} /\right.$ Piperidine $) \quad 84 / 74 \%$, 0.315/0.278 g; IR (KBr) 3421, 3248, 3039, 3098, 1702, $1335 \mathrm{~cm}^{-1}$; ${ }^{1} \mathrm{HNMR}$ (400 MHz, DMSO) $\delta 11.18$ (s. $1 \mathrm{H}, \mathrm{NH}$ indole), 8.22 (s, $2 \mathrm{H}, \mathrm{NH}_{2}$ ), 6.72-8.57 (m, 3H, Ar-H), 2.90 (s, 1H, NH); ${ }^{13} \mathrm{CNMR}$ (400 MHz, DMSO) 192.38, 165.21, $160.53,159.02,143.76,138.43,126.87,121.48,111.56,77.23$, 36.17 ppm. Anal. Calcd for $\mathrm{C}_{14} \mathrm{H}_{6} \mathrm{~N}_{4} \mathrm{O}_{5} \mathrm{~S}_{2}$ : C, 44.92; $\mathrm{H}, 1.62$; N, 14.94. Found: C, $44.72 ; \mathrm{H}, 1.64 ; \mathrm{N}, 14.94 ; \mathrm{MS}:[\mathrm{M}]^{+}$at $\mathrm{m} / z$ 373.98 .

4.5.12. 11-Amino-2-thioxo-5-methyl-10-oxo-thiazolo $\left[5^{\prime \prime}, 4^{\prime \prime}\right.$ : $\left.5^{\prime}, 6^{\prime}\right]$ pyrano $\left[4^{\prime}, 3^{\prime}: 3,4\right]$ furo[2,3-b]indole(51). Brown solid, mp $356^{\circ} \mathrm{C}$, Yield $\left(\mathrm{NiO}_{100} /\right.$ Piperidine) $87 / 71 \%, 0.30 / 0.245 \mathrm{~g}$; IR (KBr) 3411, 3228, 3013, 3090, 1720, $1320 \mathrm{~cm}^{-1} ;{ }^{1} \mathrm{H}$ NMR (400 MHz, DMSO) $\delta 10.18$ (s. $1 \mathrm{H}, \mathrm{NH}$ indole), 7.44 (s, 2H, $\mathrm{NH}_{2}$ ), 6.98-8.84 (m, 3H, Ar-H), 3.01 (s, 3H, $\mathrm{CH}_{3}$ ), 2.81 (s, $1 \mathrm{H}, \mathrm{NH}) \mathrm{ppm} ;{ }^{13} \mathrm{CNMR}$ (400 MHz, DMSO) 195.22, 167.47, $162.88,131.12$, 127.88, 123.72, 118.44, 110.47, 78.45, 40.46, 34.42, 24.77 ppm. Anal. Calcd for $\mathrm{C}_{15} \mathrm{H}_{9} \mathrm{~N}_{3} \mathrm{O}_{3} \mathrm{~S}_{2}$ : C, 52.47; H, 2.64; N, 12.24. Found: C, 52.65; H, 2.66; N, 12.27; MS: $[\mathrm{M}]^{+}$at $m / z 343.01$.

\section{Acknowledgments}

The authors are thankful to the Dean, Professor P. K. Das, and to the Head of the Department, Professor K. Singh (Science and Humanities), FET, MITS, for providing necessary research facilities in the department. Financial assistance from FET, MITS is gratefully acknowledged. They are also thankful to the Director, SAIF, Punjab University, Chandigarh for the spectral and elemental analyses.

\section{References}

[1] R. A. Sheldon and J. Dakka, "Heterogeneous catalytic oxidations in the manufacture of fine chemicals," Catalysis Today, vol. 19, no. 2, pp. 215-245, 1994.

[2] R. A. Sheldon, "Catalysis and pollution prevention," Chemistry \& Industry, vol. 1, pp. 12-15, 1997.

[3] J. H. Clark and D. J. Mac Quarrie, "Catalysis of liquid phase organic reactions using chemically modified mesoporous inorganic solids," Chemical Communications, no. 8, pp. 853-860, 1998.

[4] R. A. Sheldon and R. S. Downing, "Heterogeneous catalytic transformations for environmentally friendly production," Applied Catalysis A, vol. 189, no. 2, pp. 163-183, 1999.

[5] F. Lu, J. Ruiz Aranzaes, and D. Astruc, "Efficient mono- and bifunctionalization of polyolefin dendrimers by olefin metathesis," Angewandte Chemie, vol. 44, pp. 7399-7404, 2005.

[6] D. Astruc, "Palladium nanoparticles as efficient green homogeneous and heterogeneous carbon-carbon coupling precatalysts: a unifying view," Inorganic Chemistry, vol. 46, pp. 1884-1894, 2007.

[7] L. S. Zhong, J. S. Hu, Z. M. Cui, L. J. Wan, and W. G. Song, "In-situ loading of noble metal nanoparticles on hydroxylgroup-rich titania precursor and their catalytic applications," Chemistry of Materials, vol. 19, pp. 4557-4562, 2007. 
[8] E. Moreno-Manas and R. Pleixats, "Formation of carbon-carbon bonds under catalysis by transition-metal nanoparticles," Accounts of Chemical Research, vol. 36, pp. 638-643, 2003.

[9] Y. Li, E. Boone, and M. A. El-Sayed, "Size effects of PVP-Pd nanoparticles on the catalytic suzuki reactions in aqueous solution," Langmuir, vol. 18, pp. 4921-4925, 2002.

[10] D. Astruc, Ed., Nanoparticles and Catalysis, vol. 1, 2008.

[11] L. Djakovitch, K. Koehler, and J. G. De Vries, "The role of palladium nanoparticles as catalysts for carbon-carbon coupling reactions," in Nanoparticles and Catalysis, vol. 65, pp. 303-348, 2008.

[12] J. Durand, E. Teuma, and M. Gomez, "An overview of palladium nanocatalysts: surface and molecular reactivity," European Journal of Inorganic Chemistry, vol. 2008, pp. 3577-3586, 2008.

[13] H. H. Kung, Transition Metal Oxides: Surface Chemistry and Catalysis, vol. 45, Elsevier, 1989.

[14] V. E. Henrich and P. A. Cox, The Surface Science of Metal Oxides, Cambridge University Press, Cambridge, UK, 1994.

[15] C. Noguera, Physics and Chemistry at Oxide Surface, Cambridge University Press, Cambridge, UK, 1996.

[16] I. Salem, "Recent studies on the catalytic activity of titanium, zirconium, and hafnium oxides," Catalysis Reviews, vol. 45, pp. 205-296, 2003.

[17] V. Polshettiwar, B. Baruwati, and R. S. Varma, "Nanoparticlesupported and magnetically recoverable nickel catalyst: a robust and economic hydrogenation and transfer hydrogenation protocol," Green Chemistry, vol. 11, no. 1, pp. 127-131, 2009.

[18] R. J. Kalbasi and N. Mosaddegh, "Suzuki-miyaura crosscoupling reaction catalyzed by nickel nanoparticles supported on poly(N-vinyl-2-pyrrolidone) $/ \mathrm{TiO}_{2}-\mathrm{ZrO}_{2}$ composite," Bulletin of the Korean Chemical Society, vol. 32, no. 8, pp. 2584-2592, 2011.

[19] F. Alonso, P. Riente, and M. Yus, "Nickel nanoparticles in hydrogen transfer reactions," Accounts of Chemical Research, vol. 44 , no. 5 , pp. 379-391, 2011.

[20] M. Bandini and A. Eichholzer, "Catalytic functionalization of Indoles in a new dimension," Angewandte Chemie, vol. 48, no. 51, pp. 9608-9644, 2009.

[21] H. Takayama, "Chemistry and pharmacology of analgesic indole alkaloids from the rubiaceous plant, Mitragyna speciosa," Chemical \& Pharmaceutical Bulletin, vol. 52, no. 8, pp. 916-928, 2004.

[22] I. Chiyanzu, C. Clarkson, P. J. Smith et al., "Design, synthesis and anti-plasmodial evaluation in vitro of new 4aminoquinoline isatin derivatives," Bioorganic and Medicinal Chemistry, vol. 13, no. 9, pp. 3249-3261, 2005.

[23] K. Huber, J. Schemies, U. Uciechowska et al., "Novel 3arylideneindolin-2-ones as inhibitors of $\mathrm{NAD}^{+}$-dependent histone deacetylases (sirtuins)," Journal of Medicinal Chemistry, vol. 53, no. 3, pp. 1383-1386, 2010.

[24] M. M. Khafagy, A. H. El-Wahas, F. A. Eid, and A. M. El-Agrody, "Synthesis of halogen derivatives of benzo[ $h]$ chromene and benzo $[a]$ anthracene with promising antimicrobial activities," Il Farmaco, vol. 57, no. 9, pp. 715-722, 2002.

[25] R. M. Williams and R. J. Cox, "Paraherquamides, brevianamides, and asperparalines: laboratory synthesis and biosynthesis. An interim report," Accounts of Chemical Research, vol. 36, no. 2, pp. 127-139, 2003.

[26] J. F. M. Da Silva, S. J. Garden, and A. C. Pinto, "The chemistry of Isatins: a review from 1975 to 1999," The Journal of the Brazilian Chemical Society, vol. 12, pp. 273-324, 2001.
[27] M. Y. Chang, C. L. Pai, and Y. H. Kung, "Synthesis of ( \pm coerulescine and a formal synthesis of $( \pm)$-horsfiline," Tetrahedron Letters, vol. 46, no. 49, pp. 8463-8465, 2005.

[28] S. P. Baran and R. M. Richter, "Enantioselective total syntheses of welwitindolinone A and fischerindoles I and G," Journal of the American Chemical Society, vol. 127, no. 44, pp. 15394-15396, 2005.

[29] S. T. Hilton, T. C. T. Ho, G. P. ljevaljcic, and K. Jones, "A new route to spirooxindoles," Organic Letters, vol. 2, pp. 2639-2641, 2000.

[30] T. Kosuge, K. Tsuji, K. Hirai, K. Yamaguchi, Y. Okamoto, and T. Iitaka, "Isolation and structure determination of a new marine toxin, neosurugatoxin, from the Japanese Ivory Shell, Babylonia japonica," Tetrahedron Letters, vol. 22, no. 35, pp. 3417-3420, 1981.

[31] M. J. Kornet and A. P. Thio, "Oxindole-3-spiropyrrolidines and -piperidines. Synthesis and local anesthetic activity," Journal of Medicinal Chemistry, vol. 19, no. 7, pp. 892-898, 1976.

[32] A. Benazzouz, T. Boraud, P. Dubedat, A. Boireau, J. M. Stutzmann, and C. Gross, "Riluzole prevents MPTP-induced parkinsonism in the rhesus monkey: a pilot study," European Journal of Pharmacology, vol. 284, no. 3, pp. 299-307, 1995.

[33] D. V. Patel, K. Rielly-Gauvin, D. E. Ryono et al., " $\alpha$-hydroxy phosphinyl-based inhibitors of human renin," Journal of Medicinal Chemistry, vol. 38, no. 22, pp. 4557-4569, 1995.

[34] F. Haviv, J. D. Ratajczyk, R. W. De Net et al., "3-[1-(2benzoxazolyl)hydrazino]propanenitrile derivatives: inhibitors of immune complex induced inflammation," Journal of Medicinal Chemistry, vol. 31, no. 9, pp. 1719-1728, 1988.

[35] A. A. Nagel, D. R. Liston, S. Jung et al., "Design and synthesis of 1-heteroaryl-3-(1-benzyl-4-piperidinyl)propan-1-one derivatives as potent, selective acetylcholinesterase inhibitors," Journal of Medicinal Chemistry, vol. 38, no. 7, pp. 1084-1089, 1995.

[36] B. L. Mylari, E. R. Larson, T. A. Beyer et al., "Novel, potent aldose reductase inhibitors: 3,4-Dihydro-4-oxo-3-[[5(trifluoromethyl)-2-benzothiazolyl]methyl]-1- phthalazineacetic acid (zopolrestat) and congeners," Journal of Medicinal Chemistry, vol. 34, no. 1, pp. 108-122, 1991.

[37] D. J. Hadjipavlou-Litina and A. A. Geronikaki, “Thiazolyl and benzothiazolyl Schiff bases as novel possible lipoxygenase inhibitors and anti inflammatory agents. Synthesis and biological evaluation," Drug Design and Discovery, vol. 15, no. 3, pp. 199-206, 1998.

[38] S. K. Sohn, M. S. Chang, W. S. Choi et al., "Biochemical and pharmacological characteristics of a newly synthesized $\mathrm{H}^{+}-\mathrm{K}^{+}$ATPase inhibitor, YJA20379-1, 2-amino-4,5-dihydro8-phenylimidazole [2,1-b] thiazolo[5,4-g]benzothiazole," Canadian Journal of Physiology and Pharmacology, vol. 77, no. 5, pp. 330-338, 1999.

[39] C. W. Phoon, P. Y. Ng, A. E. Ting, S. L. Yeo, and M. M. Sim, "Biological evaluation of hepatitis c virus helicase inhibitors," Bioorganic \& Medicinal Chemistry Letters, vol. 11, no. 13, pp. 1647-1650, 2001.

[40] G. R. Green, J. M. Evans, and A. K. Vong, "Pyrans and their benzo derivatives synthesis," in Comprehensive Heterocyclic Chemistry II, A. R. Katritzky, C. W. Rees, and E. F. V. Scriven, Eds., vol. 5, p. 469, Pergamon Press, Oxford, UK, 1995.

[41] A. D. Litt and J. E. Engelhart, "Esso Research and Engineering Co, Ger Often 2, 123, 312 (Cl CO7d, 09 Dec 1971)," US Appl 25 May, 42, 1970. 
[42] W. E. Krikpatrick, T. Okabe, I. W. Hillyard, R. K. Robins, and A. T. Dren, "3-Halo-5,7-dimethylpyrazolo[1,5-A]pyrimidines, a nonbenzodiazepinoid class of antianxiety agents devoid of potentiation of central nervous system depressant effects of ethanol or barbiturates," Journal of Medicinal Chemistry, vol. 20, no. 3, pp. 386-393, 1977.

[43] A. A. Elagamy, F. M. A. El-Taweel, F. A. Amer, and H. H. Zoorob, "Reactions with 4-(Cyanoacetyl)phenazone: synthesis of novel thiazole, hydrazinopyrazole and pyrazolo[5.1-c][1.2.4] triazine derivatives," Archiv der Pharmazie, vol. 320, no. 3, pp. 246-252, 1987.

[44] M. Nogueras, J. N. Low, J. Quiroga et al., "Control of the reaction between 2-aminobenzothiazoles and Mannich bases. Synthesis of pyrido[2,1-b][1,3]benzothiazoles versus $[1,3]$ benzothiazolo[2,3-b] quinazolines," Journal of the Chemical Society, Perkin Transactions 1, vol. 4, pp. 555-559, 2002.

[45] I. Hutchinson, S. A. Jennings, B. R. Vishnuvajjala, A. D. Westwell, and M. F. G. Stevens, "Antitumor benzothiazoles. 16. Synthesis and pharmaceutical properties of antitumor 2-(4aminophenyl)benzothiazole amino acid prodrugs," Journal of Medicinal Chemistry, vol. 45, no. 3, pp. 744-747, 2002.

[46] R. N. Sharma, F. P. Xavier, K. K. Vasu, S. C. Chaturvedi, and S. S. Pancholi, "Synthesis of 4-benzyl-1,3-thiazole derivatives as potential anti-inflammatory agents: an analogue-based drug design approach," Journal of Enzyme Inhibition and Medicinal Chemistry, vol. 24, pp. 890-897, 2009.

[47] L. D. S. Yadav and A. Singh, "Multi-component synthesis of pyran-annulated thiazoles under solvent-free microwave irradiation," Synthesis, vol. 15, pp. 2395-2399, 2003.

[48] V. S. Rao, S. V. S. Arun Kumar Gupta, P. Giridhar, N. Jai Ganesh, and B. S. Reddy, "Synthesis of pyranothiazoles and spirothiazolidinediones," Indian Journal of Heterocyclic Chemistry, vol. 9, no. 4, pp. 247-250, 2000.

[49] V. L. M. Guarda, M. Perrissin, I. R. Pitta, S. L. Galdino, and C. Luu Duc, "Thiazolidinediones: reactivity of the active methylene group," Heterocyclic Communications, vol. 3, no. 4, pp. 301-306, 1997.

[50] A. Dandia, H. Taneja, and M. Saha, "Synthesis of novel spiro[indole-pyranoimidazole] and spiro[indolepyranopyrrole]derivatives," Indian Journal of Chemical Technology, vol. 4, no. 5, pp. 243-246, 1997.

[51] A. Dandia, H. Taneja, R. Gupta, and S. Paul, "An efficient procedure for the synthesis of spiro [3H-indole-3,4' $(1$ ' $\mathrm{H})$ pyrano [2,3-C] pyrrole]-5'-carbonitriles using solid inorganic supports and microwave activation," Synthetic Communications, vol. 29, no. 13, pp. 2323-2335, 1999.

[52] H. Sachdeva and D. Dwivedi, "Lithium-Acetate-Mediated Biginelli One-Pot Multicomponent Synthesis under Solvent-Free Conditions and Cytotoxic Activity against the Human Lung Cancer Cell Line A549 and Breast Cancer Cell LineMCF7," The Scientific World Journal, vol. 2012, Article ID 109432, 9 pages, 2012.

[53] H. Sachdeva, R. Saroj, S. Khaturia, and H. L. J. Singh, "Comparative studies of lewis acidity of alkyl-tin chlorides in multicomponent biginelli condensation using grindstone chemistry technique," Journal of the Chilean Chemical Society, vol. 57, no. 1, pp. 1012-1016, 2012.

[54] A. Dandia, R. Singh, H. Sachdeva, and K. Arya, "Microwave assisted one pot synthesis of a series of trifluoromethyl substituted spiro [indole-triazoles]," Journal of Fluorine Chemistry, vol. 111, no. 1, pp. 61-67, 2001.
[55] A. Dandia, H. Sachdeva, and R. Singh, "Improved synthesis of 3-spiro indolines in dry media under microwave irradiation," Synthetic Communications, vol. 31, no. 12, pp. 1879-1892, 2001.

[56] A. Dandia, R. Singh, H. Sachdeva, R. Gupta, and S. Paul, "Microwave promoted and improved thermal synthesis of spiro[indole-pyranobenzopyrans] and spiro[indole-pyranoimidazoles]," Journal of the Chinese Chemical Society, vol. 50, no. 2, pp. 273-278, 2003.

[57] A. Dandia, H. Sachdeva, and R. Singh, "Montmorillonite catalysed synthesis of novel spiro[3H-indole-3,3' - [3H-1,2,4] triazol]-2(1H) ones in dry media under microwave irradiation," Journal of Chemical Research, vol. 2000, no. 6, pp. 272-275, 2000.

[58] K. Higashiyama and H. Otomasu, "Spiro heterocyclic compounds. III. Synthesis of spiro[oxindole-3, $4^{\prime}-\left(4^{\prime} \mathrm{H}-\right.$ pyran $\left.)\right]$ compounds," Chemical \& Pharmaceutical Bulletin, vol. 28, no. 2, pp. 648-651, 1980.

[59] K. C. Joshi, R. Jain, K. Sharma, S. K. Bhattacharya, and R. K. Goel, "Studies in spiro-heterocycles. Part-XII. Synthesis of some fluorine containing spiro[3H-indole-3,4(4H)pyrano[2,3- $d$ ]pyrimidine]-2,5,7(1H)-triones as CNS agents," Journal of the Indian Chemical Society, vol. 115, pp. 202-204, 1988.

[60] A. Dandia, H. Sachdeva, R. Singh, and C. S. Sharma, "Microwave assisted one pot synthesis of novel 11-amino3-phenyl-2-thioxo-10-oxo-imidazolo[ $\left[5^{\prime \prime}, 4^{\prime \prime}: 5^{\prime}, 6^{\prime}\right]$ pyrano[ $\left[4^{\prime}, 3^{\prime}\right.$ : 3,4] furo[2,3-b]indoles," Indian Journal of Chemistry B, vol. 42, pp. 140-144, 2003.

[61] B. Sun and H. Sirringhaus, "Solution-processed zinc oxide fieldeffect transistors based on self-assembly of colloidal nanorods," Nano Letters, vol. 5, no. 12, pp. 2408-2413, 2005.

[62] Q. Li, L. S. Wang, B. Y. Hu, C. Yang, L. Zhou, and L. Zhang, "Preparation and characterization of $\mathrm{NiO}$ nanoparticles through calcination of malate gel," Materials Letters, vol. 61, no. 8-9, pp. 1615-1618, 2007.

[63] A. Kotal, T. K. Paira, S. Banerjee, and T. K. Mandal, "Ultrasound-induced in situ formation of coordination organogels from isobutyric acids and zinc oxide nanoparticles," Langmuir, vol. 26, no. 9, pp. 6576-6582, 2010. 

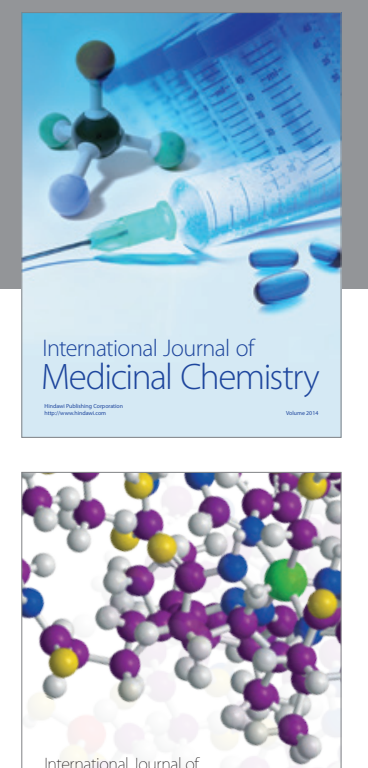

\section{Carbohydrate} Chemistry

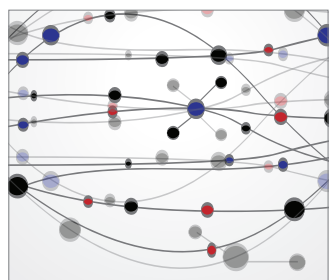

The Scientific World Journal
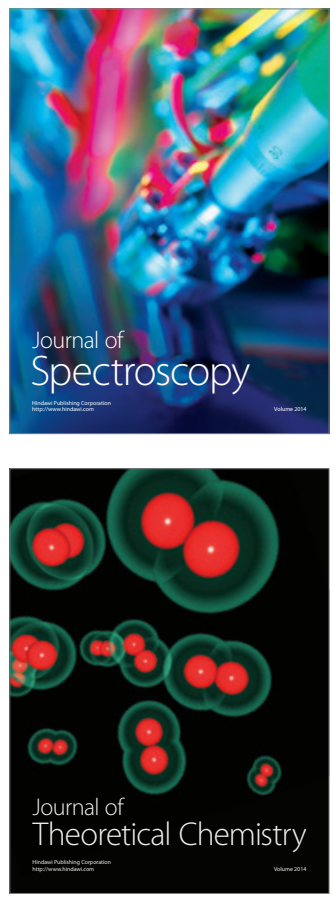
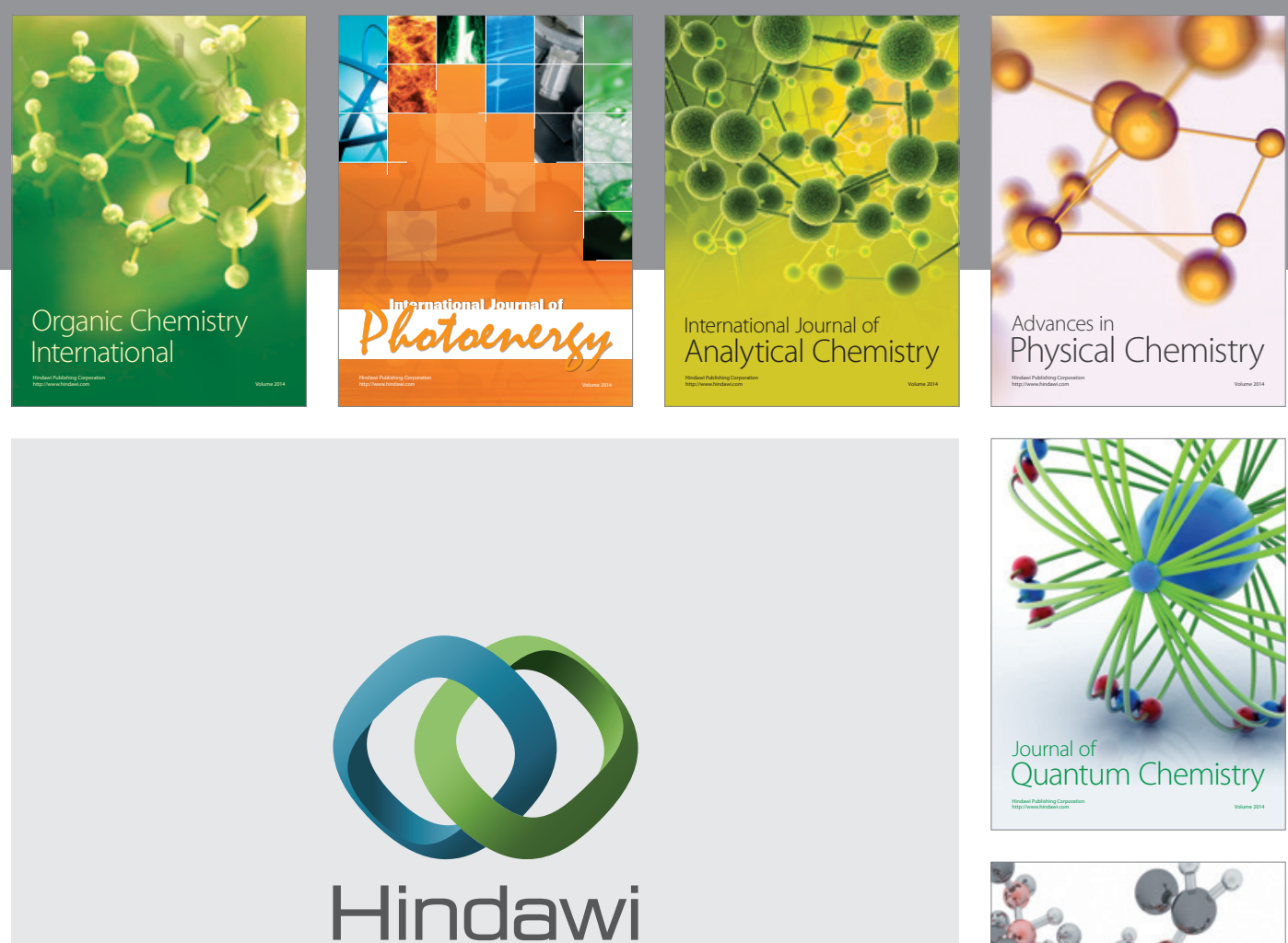

Submit your manuscripts at

http://www.hindawi.com

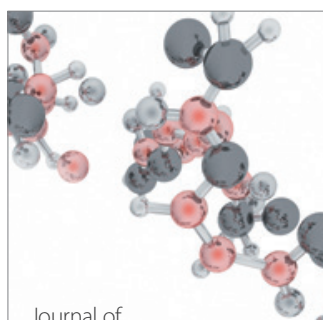

Analytical Methods

in Chemistry

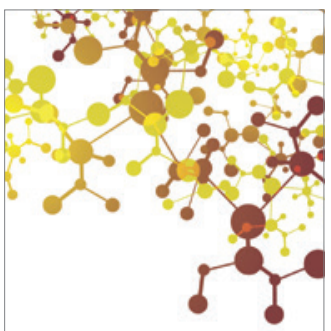

Journal of

Applied Chemistry

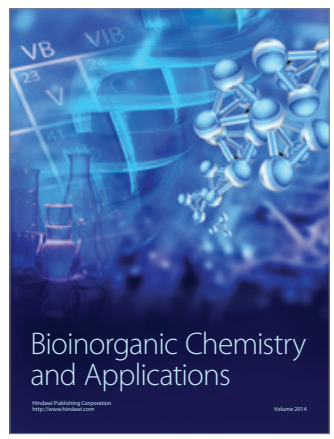

Inorganic Chemistry
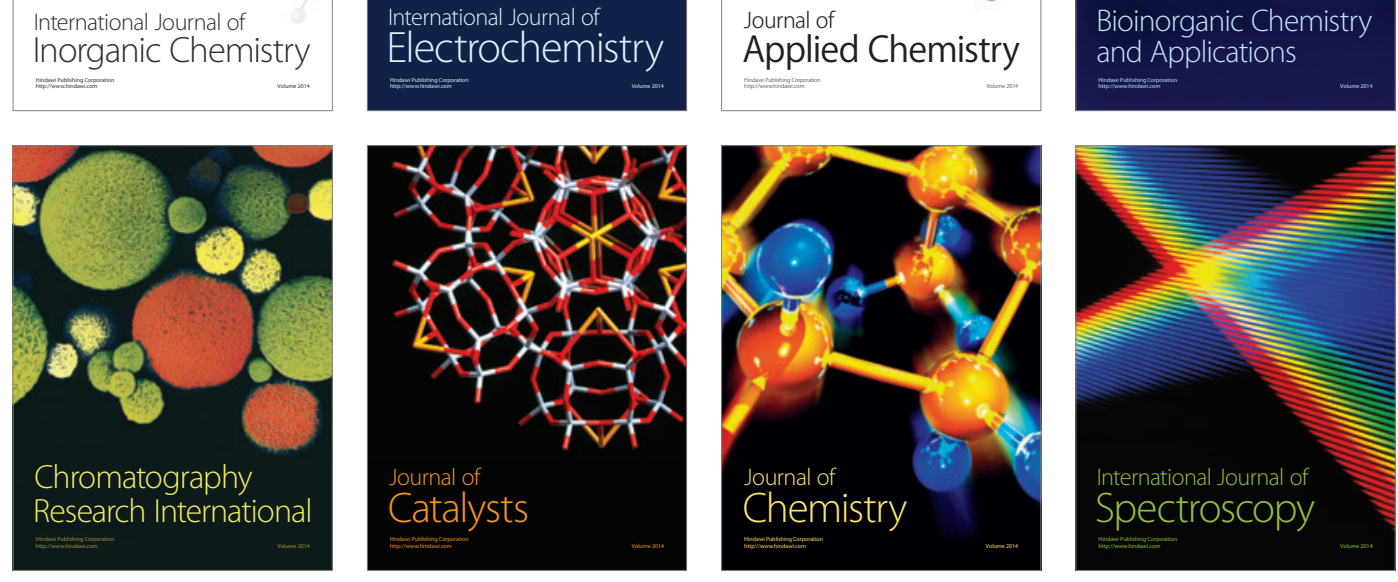